\title{
BASIC STRUCTURE OF A GENDER-SPECIFIC TRAINING COURSE FOR WORKING WITH YOUNG PEOPLE (STUDENTS)
}

\section{Kostina T. O.}

\section{INTRODUCTION}

Modern Ukrainian society is in a difficult social, economic, and political situation. The considerable number of changes in the sociopolitical system requires the person to understand the changes that our country must undergo.

The development of the state, as well as the development of the individual, is always accompanied by changes. This principle is reflected in the law of the negation of negation, which indicates the direction and forms of development. This law emphasizes the unity of the sustainable and the variable, that the new is born on the basis of the "old" that was. The main task for both the individual and society as a whole is to understand the possible ways of development and to identify those that should contribute to the highest efficiency of the organism (in the broad sense of the word).

It should be remembered that development is often a painful process that, due to the existing pain (physical or psychological), can block a person's desire for vital change. Such changes for Ukrainian society are gender issues, which are primarily related to the issue of gender inequality and manifestations of gender discrimination. Unfortunately, there are still people in Ukraine (including statesmen) who are not aware of the importance of this issue and the benefit that Ukrainian society will gain from implementing a gender approach in various spheres of public life.

Working with young people (students) is one way to tackle gender inequality. The introduction of training and educational courses on gender equality will allow young people to understand and feel the positive developments that reduce the level of discriminatory behavior. The development of a modern young man must take into account the changes that are taking place at the global level. In particular, examples from 
Western countries have shown the effectiveness of the gender approach (Sweden, Canada, USA).

The task of modern society is to help young people in their development. Such assistance is of particular importance in the context of educational institutions, since it is in them that a large part of life is spent by every young person. The introduction of gender-based courses for students (as a way of combating gender inequality and manifestations of gender-based discrimination) should help students understand the importance of this issue. But it will allow to realize that human development, its personal growth is not possible without rethinking norms and patterns established in the environment. This is especially true of gender stereotypes, which very often interfere with the development of a person and the achievement of goals that are relevant to her/him.

The relevance of the issue of psychological support for the development of personality for pedagogical and psychological science has made our scientific choice today. The results of the scientific search are presented in the form of the basic structure of a gender-specific training course for working with young people.

\section{General structure of the training course on gender issues}

The development and implementation of training programs to prevent gender inequality and gender discrimination should be based on methodological principles for the creation of training courses and should include a methodological background. The development of any training includes a content component that is related to the topics that the course is dedicated to; and a methodical component based on generally accepted principles for the development of training courses. In this subsection, we will focus on the methodological aspects of training, which determine the stage of training work.

The development of training courses has been addressed by such scholars as: I. Vachkov', V. Klimchuk ${ }^{2}$, V. Levi ${ }^{3,}{ }^{4}$, D. Ramendyk ${ }^{5}$, K. Fopel ${ }^{6}$ and others. The writings of these authors provide exercises for

\footnotetext{
${ }^{1}$ Вачков И. Основы технологии группового тренинга. М.: Издательство «Ось-89», 1999. 256 с.

${ }^{2}$ Климчук В.А. Тренинг внутренней мотивации. СПб.: Речь, 2005. 76 с.

3 Леви В.Л. Искусство быть другим. Л.: Глобус, 2000. 254 с.

4 Леви В.Л. Искусство быть собой. Л.: Глобус, 2000. 254 с.

${ }^{5}$ Рамендик Д. М. Тренинг личностного роста. Изд.: Форум, 2007. 82 с.

${ }^{6}$ Фопель К. Психологические группы: Рабочие материалы для ведущего: Практическое пособие. К. : Пер. с нем. 2-е изд., стер. М.: Генезис, 2000. 256 с.
} 
group training. In addition, the specificity of the application of the exercises and their expediency (effectiveness) in accordance with the stages of deployment of group dynamics are explained. In addition, the development of a training course should be based on the age characteristics of the participants who will participate in this interaction ${ }^{7,8}$.

The main points to be addressed in the context of dealing with gender issues are the following:

- expanding the reflection of the individual about himself and social expectations of what the personality should be;

- acquiring information on gender, gender (inequality), gender discrimination;

- highlighting the gender component in the system of social stereotypes both at the level of society and at the level of personality;

- formation of the desire to make changes in one's life (going beyond gender stereotypes).

It should be noted that working with stereotypes should involve a process of awareness that is, first and foremost, ensured by the unfolding of the individual's reflection on himself and the established social norms that the individual is confronted with. In order to develop a person's awareness of themselves and existing stereotypes, it is appropriate to include components in the program that will address different areas of the participants' psyche.

Awareness of oneself (including gender-based stereotypes) will be effective when it occurs at three levels: cognitive (information block), emotional-motivational (experience, attitude towards it) and includes a volitional component (my actions aimed at change) situation). Therefore, the training should use exercises that cover all the specified areas of the human psyche.

When it comes to the substantive component of this type of training, it should include a theoretical component: the basics of gender theory, the peculiarities of gender stereotyping, examples of cases (including advocacy campaigns) that demonstrate an individual's ability to be beyond gender-based expectations.

The training program on gender equality in general should include the following structural elements (blocks):

\footnotetext{
${ }^{7}$ Абрамова Г.С. Возрастная психология. Екатеринбург: Деловая книга, 1999. 621 с.

${ }^{8}$ Божович Л.И. Проблемы формирования личности: Избр. психол. тр. / Под ред. Д.И. Фельдштейна; Рос. акад. образования, Моск. психол.-соц. ин-т. 3-е изд. М.: МПСИ. 2001. 349 с.
} 
1 block (1 lesson) - dating;

Unit 2 (2-9 sessions) - acquaintance with basic concepts of gender theory, definition of basic gender stereotypes, reflection of participants' experience, which included gender-based discrimination; understanding the possibility of changing stereotypes and choosing to go beyond them; building a future plan for combating gender-based discrimination and establishing gender equality;

3 block (10-th session) - completion of training work.

The first session lays the groundwork for further training group work. The atmosphere created at this stage greatly influences the dynamics of further group processes. The peculiarity of this type of training is the need for a friendly atmosphere, since only under such conditions is it possible to reveal one's personality, including in the issue of gender-based discrimination. The first block is aimed at creating a friendly relationship between the participants and the trainer, the formation of a favorable psychological climate, a sense of security of the individual in the group.

The lessons of the second block form the central part of the program. For the effective realization of the set tasks, the participants are offered exercises, the performance of which determines the process of unfolding reflection on gender stereotypes and manifestations of gender inequality in society.

Reflection is carried out through the analysis of personality characteristics; social expectations about the gender distribution of roles (gender stereotypes) ${ }^{9}$, that influence a person's subsequent assessment of her/his "femininity", "masculinity"; looking at the social roles of women and men from a different perspective (analyzing how the existing distribution determines and then analyzing how it can be changed $)^{10}$.

Group dynamics allow the participant to share their own experience and hear the experience of others. This form of work covers not only the cognitive level (information) but also the emotional-motivational level ${ }^{11,12}$.

The training format allows a person to really "relive" the knowledge provided during the training. Because information delivery is always accompanied by exercises that allow you to update a person's past

\footnotetext{
${ }^{9}$ Говорун Т.В., Кікінежді О.М. Стать та сексуальність: психологічний ракурс. Тернопіль: Навчальна книга - Богдан, 1999. 343 с.

${ }^{10}$ Бем С. Линзы гендера: Трансформация взглядов на проблему неравенства полов / [пер. с англ.]. М.: «Российская политическая энциклопедия» (РОССПЭН), 2004. 336 с.

${ }_{11}^{11}$ Перлз Ф. Практика гештальттерапии. М.: Институт Общегуманитарных Исследований, 2005. 480 с.

12 Ялом И. Групповая психотерапия. Теория и практика. М.: Апрель Пресс, Изд-во ЭКСМО-Пресс, 2001. 576 c.
} 
experience, "relive" the experience of other participants and gain emotional experience of interacting in the group. Due to this form of work, there is a process of conglomeration of the individual's partial knowledge about gender in a coherent system of the concept of "gender (in) equality". Exercising the program should contribute to the formation and realization of the life plan of the person beyond the established gender patterns.

The third block of the correction program is aimed at creating favorable conditions for the exit of the individual from the training. The total duration of the training program may be 10 weeks.

The program is aimed at participants aged 18 and over. This age group already has the necessary resources for training in this format. In particular, developed reflection, the quest for self-knowledge, as well as the desire to exercise oneself in this world (search for oneself, partner, friends, etc. $)^{13,14}$. It is during this age period that man is not only able to "go against society" (which is typical for adolescents), but to build his own path. Due to the psychological peculiarities of this age category, the introduction of such training courses will help to increase the level of selfawareness, existing social stereotypes (including gender), which will help to develop a person who is able to strive to establish gender equality and reduce the level of gender discrimination ${ }^{15}$.

It should be noted that the proposed training structure ( 3 blocks) is of a general nature and can be adjusted in accordance with the time (limitations of the training course related to the educational process), quantitative (number of participants) and qualitative indicators (group composition), with which the psychologist/trainer will work.

\section{The content of the training course "Gender (in) equality: I can do more!"}

\section{Lesson 1.}

The purpose of the first lesson is to: formulate the rules of the training group, get acquainted with the participants, create a friendly atmosphere.

At the beginning of the first session, the trainer determines the basic rules of the training work that must be observed by each member of the

\footnotetext{
${ }_{13}^{13}$ Малкина-Пых И.Г. Справочник практического психолога. М.: Изд-во Эксмо, 2007. 784 с.

${ }_{11}^{14}$ Райс Ф., Долджин К. Психология подросткового и юношеского возраста. СПб.: Питер, 2012. 816 с.

15 Як навчати школярів долати гендерні стереотипи: конспекти занять / навч.-метод. посібник для загальноосвітніх навчальних закладів. Т. Говорун, О. Кікінежді та ін., за заг.ред. професора Т. Говорун. К.: ТОВ «Дорадо-Друк», 2006. 804 с.
} 
group. Participants are given the opportunity to complete the list of rules. The basic rules to be followed during the training are:

- Privacy (information remains within the group and cannot be released);

- Activity (participants should "get involved" in the group work, participate in exercises and discussion);

- The principle of "here and now" (participants should be present not only physically but also psychologically);

- To say "I", not "we" or "all" (raises responsibility for one's words, actions, because I speak for myself, not for others);

- Stop rule applies - a participant has the right to refuse to discuss a particular issue or to complete a task;

- Prohibition of criticism (we analyze the results but do not criticize the individual);

- "Better in the circle than home!" (all experiences, thoughts that involve group members are better spoken in the group, shared with other members than carrying this "luggage" home. This rule helps to create and maintain open communication in the group).

Sometimes group members may also suggest additional rules. For example, getting started, disconnecting mobile phones, etc. is timely.

Prior to the exercise of the first session, the trainer hands out badges to participants, on which they write down their name. Now each team member and coach can speak to each other by name.

Exercise "Questionnaire": The purpose of this exercise is to give participants an opportunity to get to know each other better. Identify similar events among group members. Participants are provided with a questionnaire describing cases of gender inequality and gender discrimination.

After the participants have filled in the questionnaires, the trainer reads the answers. If a certain point has taken place in an individual's life, he / she will raise their hands. In this way, others can see that similar situations were in the lives of other participants. So, participants understand that they have a lot in common. And there is still a lot of gender inequality and discriminatory manifestations in Ukrainian society.

Participants are then encouraged to team up with two participants with whom they have a similar response and discuss past experiences together. 
Exercise "Hand": The purpose of this exercise is to establish an atmosphere of trust in the group; determining the presence of stereotypes of other people's perceptions (especially in the context of gender stereotypes).

The group members offer the following instruction: "You should now contact the partners you wanted to work with. You have to sit opposite each other. One of you reaches out your hand so that the other can get to know it well. You have to look it from the sides, touch it, rotate it. Get her size, hand shape, decorate. Trying to evaluate your hand as a symbol and increase your partners' holistic representatives. By my signal, you are changing roles: now your partner should familiarize themselves with your hand. After the exercise, you should make a presentation to your partner (based on your impressions of him /her hand).

After completing the first part, participants are given additional instruction: "now you will be presenting your partner. You should describe what he (s) is characteristic of, based on the impression of learning about his (her) hand. After the presentation, your partner gives you feedback: what is relevant to him (her) in your presentation and what is not, that is, false".

Sharing: Discussion of an activity during which participants give feedback on the experience, impressions, wishes, satisfaction / dissatisfaction with the activity, etc.

\section{Lesson 2.}

Starting from the second lesson, the participants will be offered exercises and tasks aimed at stimulating awareness and understanding of the existing gender stereotypes and discriminatory manifestations in society. The second block (2-9 sessions) enables the individual to recall the events of his or her own life, to analyze them, to highlight the manifestations of gender inequality and gender-based discrimination, to adjust life decisions, to change oneself and their attitude to gender issues. The second block aims to make personal changes to improve the further life path of the person beyond gender restrictive stereotypes.

Exercise "What is affecting my life?": The purpose of the exercise is to highlight the subject of factors that affect his / her life.

Instruction: "Please provide a list of factors (events, people, etc.) that affect your life. Write down everything that comes to mind". 
In the course of the exercise, the participants of the group come to the concept of external (events, other people, etc.) and internal (attitude to certain events, life choices, stereotypical beliefs, etc.) determination of life path. The understanding that a person can influence himself and influence (consciously or unconsciously) on his life is updated. Of particular importance is the awareness of who influences life and how. Were there people who acted outside the established gender stereotypes. How important they were for the band member. What events contributed to the formation of gender stereotypes, and what events, on the contrary, determined the realization that there was something more than existing social expectations. During the analysis of the exercise, the understanding that a person is influenced by the social environment is increasingly formed, but the person is not only a passive recipient of information. Everyone can take an active and transformative activity to make their lives beyond their existing prejudices.

Exercise "Circle of my life": this exercise is aimed at determining the peculiarities of the interconnection of the past, present and future on the life of the individual; definition of subjective experience of this influence.

The trainer gives the group members the following instruction: "On a piece of paper, please draw three circles. Each circle will symbolize a specific time span of your life: one circle is the past, the second is the present, the third is the future. The circles can be arranged as you like. The main thing is that they express your experience of the relationship between the past, present and future. Indicate which time interval a circle corresponds to".

After the participants have drawn the circles, a group discussion of the received psychological material.

Sharing: Discussion of an activity during which participants give feedback on the experience, impressions, wishes, satisfaction / dissatisfaction with the activity, etc.

Lesson 3.

In this session the participants' self-reflection on themselves continues. Personal beliefs (including gender-based ones) are updated, and their impact on the life of the individual is determined.

The trainer invites the participants to perform the exercise "Who am I?", which allows to identify the characteristics of selfperception of personality. 
Participants are instructed: "Please provide answers to this question. Write down everything that comes to mind. Write the statements in the order in which they occurred to you. Please provide at least 10 answers".

Exercise "My (Gender) Beliefs": The purpose of the exercise is to define the gender beliefs of the individual in relation to other people and to himself / herself.

Instruction: "Divide a piece of paper into 3 columns. The first column will contain a list of beliefs about the world around you; the second is the belief in others; the third is self-belief. Write down everything that comes to mind".

Additional instructions: "Now, in each column ( 3 in total), put a" + "or" - "in front of each conviction. A "+" sign if that belief helps you in life, a "-" sign if it interferes."

During the discussion, participants determine what beliefs they have in relation to themselves, other people, and others. They analyze the modality ("+" or "-") of these beliefs. They come to understand the interdependence of our beliefs and the specifics of interacting with the world.

The second part of this exercise is to highlight the gender component of existing beliefs. Among the recorded beliefs, participants are asked to identify those that are determined by the gender component. After completing the task, a group analysis is made of what gender beliefs are available to the group members and how these beliefs affect their interaction with the surrounding world, with other people and with themselves.

Exercise "What is Gender Discrimination?". The purpose of the exercise is to update the knowledge and experience of the group members on the subject. The trainer gives the participants the following instruction: "Join in groups of four people. Each group receives a large piece of paper on which to reflect what you think when I say, "What is gender discrimination?" It may be a certain image or something else that will embody the phenomenon of discrimination. Work in groups. You have 20 minutes to complete the task. After that we will present the works you have created. “

After the groups have completed the task, there is a presentation of the work done by each group. The presentation takes place in an active form, where each listener can ask questions about the presented material. 
Sharing: Discussion of an activity during which participants give feedback on the experience, impressions, wishes, satisfaction / dissatisfaction with the activity, etc.

\section{Lesson 4.}

In this lesson, participants will create a fairy tale. This form of work makes it possible to determine the peculiarities of the gender component of the human life scenario. In our opinion, the unfolding of a person's life is conditioned by a large number of factors and one of the main ones is the actual life scenario. It is founded in early childhood and operates at an unconscious level. The concept of life scenario was developed by E. Bern in the theory of transactional analysis ${ }^{16}$. Followers of E. Bern, such as C. Steiner ${ }^{17}$ and $\mathrm{H}$. Wickoff ${ }^{18}$ explored different types of life scenarios, in particular gender-based (typical female and male scenarios). That is why in order to understand a person's established gender beliefs, it is important to examine his or her life scenario, especially his or her gender component.

Therefore, in our training course, we invite participants to identify the specificities of their gender scenarios. One of the most appropriate methods for this is the fairy-tale therapy, which actually allows you to plunge into its life-scenario space in a casual form.

Exercise "Fairy Tale: There Was a Girl (Boy)...": Exercise gives an opportunity to explore the peculiarities of the gender component of the life scenario of the group members.

The instruction given to the participants of the training: "Today we will become a storyteller with you. Each of you will write a fairy tale that will have fairy-tale characters with whom certain fairy-tale events will take place. The fairy tale should start with the words " there was a girl (boy)...". The tale must have a beginning (how the hero was born, where and how he grew up, etc.). The following are the main events of the tale. And then the end of the tale. Heroes can have any event. There are no restrictions on the location, timing of the fairytale events. You are the author, this is your work. You create your own fairy tale. Each of you has a piece of paper on which you can write your work. So, let's begin!"

\footnotetext{
16 Берн Э. Игры, в которые играют люди. Психология человеческих взаимоотношений; Люди, которые играют в игры. Психология человеческой судьбы / пер. с англ. Екатеринбург: Литур, 2001. 576 с.

${ }^{17}$ Steiner C. Scripts People Live: Transactional Analysis of Life Scripts. Grow Press: New York, 1990. $332 \mathrm{p}$ $332 \mathrm{p}$.

Steiner C. Scripts People Live: Transactional Analysis of Life Scripts. Grow Press: New York, 1990.
} 
In the process of discussing fairy tales, the question is raised about the relationship between the events in the fairy tale, the main character and the events in the life of the group members. The "reflection" in the fairy tale that concerns the author of the fairy tale is analyzed. Topics that are important to the group members (but not always aware) are updated. The gender component of the personality scenario is raised. There is an analysis of whether there is a difference between what happens in fairy tales with heroes-boys and heroines-girls. What is the role of society, parents, environment. Is a person able to counter these stereotypes? And whether a person is able to rewrite the "fairy tale of life", which he had unconsciously adopted in his own childhood.

Sharing: Discussion of an activity during which participants give feedback on the experience, impressions, wishes, satisfaction / dissatisfaction with the activity, etc.

\section{Lesson 5.}

In this session, participants are offered information on the basics of gender theory, the history of the independence movement and women's rights (suffragettes, feminism). This is a theoretical orientation exercise, the main purpose of which is to familiarize the group members with gender issues $19,20,21$.

This lesson reveals the concept of gender approach and its importance for the further harmonious development of human society. During the training the trainer uses presentations, videos and more. The familiarization process takes place in an easy-to-use format, where each participant has the opportunity to ask questions, or to share their own experiences with the information provided by the facilitator.

Sharing: Discussion of an activity during which participants give feedback on the experience, impressions, wishes, satisfaction / dissatisfaction with the activity, etc.

\section{Lesson 6.}

In this lesson the participants of the training group continue to familiarize themselves with the theoretical basics of gender issues; the legislative background governing this issue in Ukraine is also highlighted.

\footnotetext{
${ }^{19}$ Бем С. Линзы гендера: Трансформация взглядов на проблему неравенства полов / [пер. с англ.]. М.: «Российская политическая энциклопедия» (РОССПЭН), 2004. 336 с.

${ }^{20}$ Говорун Т.В., Кікінежді О. М. Стать та сексуальність: психологічний ракурс. Тернопіль: Навчальна книга - Богдан, 1999. 343 с.

${ }^{21}$ Шевченко 3.В. Словник гендерних термінів. Черкаси: видавець Чабаненко Ю., 2016. URL: http:// a-z-gender.net/ua/\%D2\%91ender.html (дата звернення 22.08.2019).
} 
Gender Quiz Exercise. At the beginning of the class, participants are asked to take a quiz with questions related to the training topic.

The trainer offers the participants the following task: "Now we will become participants of the quiz! I will put the question on the interactive whiteboard, and you will choose the answer that you think is correct. There will be ten questions in total, which means you can score 10 points (there is one point for each correct answer). So let's get started!"

Additional instruction: "We will now check with you the correctness of our answers. So, let's look at the screen and check our answers with the correct answers".

The participants then share their results and discuss the results. There is an exchange of views as to whether the members of the group are sufficiently aware of the gender issues being addressed at the legislative level.

The quiz is followed by an information block that outlines the main legal documents that should ensure gender equality in Ukraine. It is emphasized that in Ukraine gender equality is enshrined in the Basic Law of Ukraine - Constitution ${ }^{22}$.

Successful examples of regulation of this issue in other countries of the world (Sweden, Canada, USA) are also described.

The information block concludes with examples of advocacy campaigns aimed at addressing discrimination against women and established discriminatory social stereotypes.

For example, you might suggest the video, "Why does being a girl mean bad?" (\#LikeAGirl) ${ }^{23}$. As well as video campaigns that highlight the importance of preventing gender-based discrimination (\#HeForShe) ${ }^{24}$. After watching the video, there is a discussion about how social stereotypes affect how we perceive people and how people perceive themselves (especially in the context of gender stereotypes) ${ }^{25,26}$.

The group member is given a homework assignment: "Please find further examples of advocacy campaigns that have raised issues of

\footnotetext{
${ }^{22}$ Конституція України. URL: https://zakon.rada.gov.ua/laws/show/254\%D0\%BA/96-\%D0\%B2\%D1\%80 (дата звернення: 19.08.2019).

${ }^{23}$ \#LikeAGirl https://always.com/en-us/about-us/likeagirl-how-it-all-started (дата звернення 22.08.19)

${ }^{24}$ \#HeForShe https://www.heforshe.org/en (дата звернення 21.08.19)

25 Шевченко 3.В. Словник гендерних термінів. Черкаси: видавець Чабаненко Ю., 2016. URL: http:// a-z-gender.net/ua/\%D2\%91ender.html (дата звернення 22.08.2019).

26 Куравська Н. Гендерні стереотипи як джерело гендерної дискримінації та сексизму. URL: file://D:/ГЕНДЕР2019/3729-10766-1-SM.pdf (дата звернення: 21.08.2019).
} 
discrimination against women and the oppression of their rights. At the next session, each of you will present the information you have found".

Sharing: Discussion of an activity during which participants give feedback on the experience, impressions, wishes, satisfaction / dissatisfaction with the activity, etc.

\section{Lesson 7.}

At the beginning of the class, participants share examples of advocacy campaigns (sixth class homework) that raise issues of gender inequality and discriminatory behavior.

This is followed by a main unit of study aimed at reflecting on the trainees of what it meant to be a woman of the past. The issue of lack of rights and freedom for women, which has prevailed over much of the globe and continues to this day, is still being updated. The deepening of this issue is proposed to be made using one of the methods of non-formal education - the method of theatrical decision.

Exercise "Theater". The trainer offers the participants the following instruction: "You will now join into four groups. Each group will receive a leaflet that will spell out a certain historical period. Your job is to make a mini-play that would show the situation of women during the historical period indicated on the card. You have 40 minutes to complete the exercise (information search and production scenario)".

In order for the participants to be able to make such a resolution, they need to know: what happened to women at that time; what rights did they have (or vice versa, did not have)? This exercise helps to increase the level of activity of participants of the training group. Because they need to find the information they need. The trainer can only direct, provide clarifying information, etc. However, the information itself should be sought by participants. To do this, they must use smartphones with an Internet connection.

Searching for information leads participants to realize that at all times (in our example, we wrote on the cards such periods as: Antiquity, Middle Ages, Renaissance, Modern Times), women actually had no rights and were the "property" of male relatives. Such an opening actualizes the understanding that as it is now, it has not always been so. There have been times when women had no right to go outside the home without the support of men, that they had no rights to children, had no property rights, and no voice. Such an opening is usually quite emotional. And here it is 
very appropriate to use the method of theatrical production, since the participants have to translate their knowledge into a certain form, which should convey the information received to the audience who will watch this performance. To do this, participants need to "get on" in the role and truly feel the oppression that women have been in all this time.

Additional instruction: "Each group is now showing its miniperformances. And other participants have to guess what the historical period is all about!".

Following is a presentation of the performances. After all the groups have presented their performances, there is a collective discussion of what the participants saw, found and experienced.

Sharing: Discussion of an activity during which participants give feedback on the experience, impressions, wishes, satisfaction / dissatisfaction with the activity, etc.

\section{Lesson 8.}

This lesson continues to reflect on how women have lived in the past and what has happened in the course of the historical development of society, so that women can enjoy the rights they have today, including voting rights.

Movie Watch Exercise. The trainer offers the participants the following instruction: "In the last session, we learned about what women could do in different historical eras and what rights they were guaranteed (or, more appropriately, not guaranteed). At today's session, we will be watching the movie "Suffragette" (directed by Sarah Gavron, 2015), which will tell us about women's right to vote in the elections". After that there is a collective viewing of the movie.

At the end of the viewing, a discussion unfolds about what the participants saw in this movie. Each participant shares the impression they have seen. There is an analysis of whether the methods used by suffragettes were appropriate. How would you do in the place of the main character of the film: what would you choose a family or fight for women's rights?

After the discussion, the participants of the training group are given a homework task: to write an essay on "The value of the suffragette movement for gender equality."

Sharing: Discussion of an activity during which participants give feedback on the experience, impressions, wishes, satisfaction / dissatisfaction with the activity, etc. 


\section{Lesson 9.}

The purpose of this lesson is to create a gender advocacy campaign for the training group.

Exercise "Advocacy Campaign". The trainer offers the participants the following task: "Remember, in one session, we talked to you about legislative support for gender equality in countries. In addition, we have looked at advocacy campaigns to raise public awareness of discriminatory practices against girls and women. In particular, we were introduced to the \#HeForShe and \#LikeAGirl advocacy. Each of you also presented other examples of advocacy campaigns on gender issues. That is why today we will develop our own advocacy campaigns, which should help to reduce the level of discriminatory manifestations in Ukrainian society".

Additional instructions: "You will now join groups of 5 people. Each group must develop an advocacy campaign that the group can do on its own. Therefore, an advocacy campaign should include the following elements:

- the name that should be related to the topic you chose (in our case, it's gender);

- motto (slogan) - a short sentence that should show the main appeal for the people who will see it;

- campaign stages (stages that include a campaign: preparatory, actual campaign, analysis of results, etc.);

- deadlines (terms of campaign implementation);

- responsible persons (who is responsible for the timing and quality of implementation of the advocacy campaign in "life");

- venue and form (where exactly the campaign (village, city, region) will take place and what form it will take: online or offline);

- target audience (who this campaign is targeted to, who should "hear it").

So, you have a support scheme to help you develop your advocacy campaign. Each group has a poster and pencils where you have to mark the strong points of your campaign. So, get to work!".

Participants work in a group, the trainer can help and answer questions that may arise in the participants during the exercise.

Then the participants present their projects. Each group takes the stage one by one and talks about their campaign, drawing on the supporting 
scheme. Other participants listen carefully and ask clarifying questions. After the presentation, the results are discussed.

At the end of the class, there is a sharing: a discussion of the class, during which the participants give feedback on the experience, impressions, wishes, satisfaction / dissatisfaction with the lesson, etc.

\section{Lesson 10.}

The tenth session is the final stage of the training course "Gender (in) equality: I can do more!" The last lesson is summing up the participants of the group and its trainer. The final lesson reflects the experience gained, information on gender issues, outlines possible ways of further functioning of the individual beyond gender stereotypes. However, the final lesson aims not only to summarize, but also to encourage participants to integrate their knowledge and experience into their later lives.

Exercise "Collective experience". The trainer offers the participants the following task: "Today we have the last lesson of our training course with you. Not only did we get a lot of information and knowledge from you, but we also gained experience that could only be born during group interaction. Now, let us each draw / write something on this sheet of paper that he or she has associated with this experience. We work in complete silence".

After all the participants have completed the task, an analysis takes place. Each participant speaks of that symbol (word) that he/she depicted on this paper. Describes what it means to him/her and why he/she painted / wrote it. As a result, we get impressions of the training course.

Exercise of "Wishes for Yourself": actualization of the subject's wishes for himself and his subsequent life in the context of interaction with gender issues.

The trainer offers the participants the following instruction: "In the course of our lessons we have analyzed the situation in the society on gender issues. They researched what happened to gender discrimination at different historical stages of society. Find out which women's movements contributed to women's right to vote, and later other basic human rights. Understand how strong are the gender stereotypes that are attached to society by a person from the very beginning of his / her life. In addition, we have developed advocacy campaigns to raise public awareness of gender inequality. 
Now, based on the knowledge you have received, on the emotions you have experienced, complete the following task. On a piece of paper, write what you wish for yourself, what would you like to do in the future?".

Group Gratitude Exercise: End contact in the group.

Instruction: During our training, we made a lot of discoveries about ourselves, as well as other members of the group. We have gained group experience. And we got this experience thanks to each of the group members. Now we will do the last exercise of our training. We will pass a candle in a circle and each of you should give the band and its members a specific wish.

After completing this exercise, training ends.

The proposed structure of a gender-specific training course for working with young people (students) can be used in various higher education institutions (public, private, communal). The training can be provided in the form of an elective, or as a course of the variant part of the curriculum. In addition, coaches / psychologists / teachers can take individual exercises from this course for their training and practical activities. This structure is basic and can be supplemented according to the requirements of each individual group.

\section{CONCLUSIONS}

As a result of a scientific search, we have developed the basic structure of a gender-based training course for working with young people.

Based on the psychological characteristics of the age category of students (young people) and the specifics of working in a group format, we have developed a basic training scheme. In particular, it was determined that a training pro gramme on gender inequality in general should include the following structural elements (blocks): block 1 (1 lesson) - getting to know the group; block 2 (2-9 lessons) - acquaintance with basic concepts of gender theory, definition of basic gender stereotypes, reflection of participants' experience, which included gender-based discrimination; understanding the possibility of changing stereotypes and choosing to go beyond them; building a future plan for combating gender-based discrimination and establishing gender equality; 3 block (10 lessons) completion of training work.

The training course may contain exercises that will allow young people not only to receive information but also to experience it (for 
example, the Theater exercise). This increases the level of assimilation of the acquired information. In addition, information obtained in this way becomes the subject's "own" experience, which increases the level of its significance for the individual.

To encourage young people to be active in the training course, they include exercises that require students to take action to raise public awareness of gender issues (Exercise Advocacy Campaign).

The proposed basic structure of the training course can be used entirely by trainers / psychologists / teachers, or parts (using separate exercises in accordance with educational and pedagogical needs).

This training does not reveal all the possible approaches to working with young people (students) in the context of gender issues. However, we hope that it will come in handy when developing other training / training courses.

\section{SUMMARY}

This article is dedicated to the features of the development of genderspecific training courses when working with young people.

Attention is drawn to the fact that implementation of these courses is of particular importance in the context of the European vector of development of the Ukrainian state. It has been determined that there is a legal framework in Ukraine that regulates gender and promotes gender equality (starting with the basic law - the Constitution of Ukraine).

The work emphasizes the need to introduce training and training courses on gender orientation as a prerequisite for harmonious personal development.

It has been stated that self-awareness (including gender-based stereotypes) will be effective when it occurs at three levels: cognitive (information block), emotional-motivational (experience, attitude towards it) and includes a volitional component (my actions, aimed at changing the current situation). Therefore, the training should use exercises that cover all the specified areas of the human psyche.

The basic structure of a gender-specific training course for working with young people (students) is proposed, which can be used during the educational process, in the form of an elective or a part of a variant part of the curriculum. 
It is emphasized that psychological support for personality development cannot take place outside of gender issues, since gender issues accompany a person throughout their lives and are manifested in all spheres (social, household, economic, political, etc.).

\section{REFERENCES}

1. Абрамова Г.С. Возрастная психология. Екатеринбург: Деловая книга, 1999. $621 \mathrm{c.}$

2. Бем С. Линзы гендера: Трансформация взглядов на проблему неравенства полов / [пер. с англ.]. М.: «Российская политическая энциклопедия» (РОССПЭН), 2004. 336 с.

3. Берн Э. Игры, в которые играют люди. Психология человеческих взаимоотношений; Люди, которые играют в игры. Психология человеческой судьбы / пер. с англ. Екатеринбург: Литур, $2001.576 \mathrm{c}$.

4. Божович Л.И. Проблемы формирования личности: Избр. психол. тр. / Под ред. Д.И. Фельдштейна; Рос. акад. образования, Моск. психол.-соц. ин-т. - 3-е изд. М.: МПСИ. 2001. 349 с.

5. Вачков И. Основы технологии группового тренинга. М.: Издательство «Ось-89», 1999. 256 с.

6. Говорун Т. В., Кікінежді О. М. Стать та сексуальність: психологічний ракурс. Тернопіль: Навчальна книга - Богдан, 1999. $343 \mathrm{c}$.

7. Конституція України. URL: https://zakon.rada.gov.ua/laws/show/ 254\%D0\%BA/96-\%D0\%B2\%D1\%80 (дата звернення: 19.08.2019).

8. Климчук В.А. Тренинг внутренней мотивации. СПб.: Речь, 2005. $76 \mathrm{c}$.

9. Куравська Н. Гендерні стереотипи як джерело гендерної дискримінації та сексизму. URL: file://D:/ГЕНДЕР2019/3729-10766-1SM.pdf (дата звернення: 21.08.2019).

10. Леви В.Л. Искусство быть другим. Л.: Глобус, 2000. 254 с.

11. Леви В.Л. Искусство быть собой. Л.: Глобус, 2000. 254 с.

12. Малкина-Пых И.Г. Справочник практического психолога. М.: Изд-во Эксмо, 2007. 784 с.

13. Перлз Ф. Практика гештальттерапии. М.: Институт Общегуманитарных Исследований, 2005. 480 с. 
14. Райс Ф., Долджин К. Психология подросткового и юношеского возраста. СПб.: Питер, 2012. 816 с.

15. Рамендик Д. М. Тренинг личностного роста. Изд.: Форум, 2007. $82 \mathrm{c}$.

16. Як навчати школярів долати гендерні стереотипи: конспекти занять / навч.-метод. посібник для загальноосвітніх навчальних закладів. Т. Говорун, О. Кікінежді та ін., за заг.ред. професора Т. Говорун. К.: ТОВ «Дорадо-Друк», 2006. 804 с.

17. Фопель К. Психологические группы: Рабочие материалы для ведущего: Практическое пособие. К. : Пер. с нем. 2-е изд., стер. М.: Генезис, 2000. 256 с.

18. Шевченко 3. В. Словник гендерних термінів. Черкаси: видавець Чабаненко Ю., 2016. URL: http://a-z-gender.net/ua/\%D2\% 91ender.html (дата звернення 22.08.2019).

19. Ялом И. Групповая психотерапия. Теория и практика. М.: Апрель Пресс, Изд-во ЭКСМО-Пресс, 2001. 576 с.

20. \#HeForShe https://www.heforshe.org/en (дата звернення 21.08.19)

21. Jackson, Philip W. Classroom society. Life in classrooms. New York: Holt, Rinehart and Winston, Inc., 1968, 177 p.

22. \#LikeAGirl https://always.com/en-us/about-us/likeagirl-how-it-allstarted (дата звернення 22.08.19)

23. Steiner C. Scripts People Live: Transactional Analysis of Life Scripts. Grow Press: New York, 1990. 332 p.

\section{Information about the author:}

Kostina T. O.

Candidate of Psychological Sciences, Associate Professor at the Department of Psychology and Pedagogy of the V. I. Vernadsky Taurida National University 33, John McCain str., Kyiv, 01042, Ukraine 